\title{
Nature of the Information Seeking Behaviour of Teachers Engaged in General Degree Colleges and Teachers' Training Colleges: A Critical Analysis
}

\author{
By Dipak Kumar Kundu*
}

\begin{abstract}
The nature of the information seeking behaviour of the teachers engaged in General Degree Colleges and Teachers' Training Colleges affiliated to West Bengal State University, India, is critically analysed in the present study. The descriptive analysis is based on well structured, close-ended questionnaires which were distributed among 450 teachers. 408 of them responded from whom 376 work in General Degree Colleges and 32 in Teachers' Training Colleges. The analysis of the data shows that teachers still depend mainly on printed documents, but a changing attitude is taking place in the current ICT environment as they also start to depend on electronic documents for meeting their information needs. This paper also explores the sources used by the teachers of both groups for research activities, focusing on the variability in the use of such sources of information. Additionally, this study reveals the attitudes of the teachers towards the services provided by the libraries. It is recommended that the college libraries are restructured with internet facilities and sufficient resources, in order to meet the information needs of the college teachers. In this context, the college librarians should provide basic software training to the users, to help them access the electronic sources.
\end{abstract}

Keywords: electronic documents, general degree colleges and teachers' training colleges, information needs, information seeking behaviour

\section{Introduction}

Information is linked with the socio-economic conditions prevailing in a community and it is considered to be an important attribute of the process of social development. Due to the enormous increase in the volume of the relevant literature, especially in the field of science and technology, the present situation has given birth to the concept of information explosion. This term describes the currently occurring phenomenon of data superfluity attributed to the vast volume of published information; in this context, controlling and organizing information, in a way such that the problem of information overload is avoided, is a quite challenging task. These phenomena of information explosion and overload have created the need for an in-depth analysis of the relevant needs and information seeking behavior of different groups of users. The group under question in this study is the teacher community, being gravely concerned about the modern patterns and trends of acquiring information.

*Librarian, Satyapriya Roy College of Education, India. 
Wilson (2000) has described information-related behaviour as the totality of human behaviour in relation to sources and channels of information, including both active and passive information-seeking and use. The development of information technology has offered the academic community various opportunities to access information resources in a variety of formats; via print, CD-ROMs, databases, Web OPAC, etc.

The traditional lecture is no longer the only method available to the college teachers. They need to explore new avenues in order to make classroom teaching more interesting. The teachers engaged in training already have some sort of ideas about how to improve lectures, while those teaching in general degree colleges, and particularly the younger ones, are still in the process of seeking information on how to acquire such modern methods. This is a natural consequence of the fact that Teachers' Training Colleges (TTCs) give emphasis on the teaching methods of different subjects rather than the exhaustive approach in the subject field, being specifically concerned about the classroom teaching, lesson plan and pedagogy of various subjects. Subsequently, their information seeking patterns may differ to some extent from the teachers' of General Degree Colleges (GDCs).

This study is an attempt to assess the nature of information seeking behaviour of the teachers engaged in the Teachers' Training Colleges and General Degree Colleges affiliated to West Bengal State University, India.

\section{Objectives of the Study}

The objectives of this study are:

1. To analyze the nature of the information seeking behaviour of the teachers engaged in both the General Degree Colleges and Teachers' Training Colleges, affiliated to WBSU.

2. To study the sources used by the teachers of both groups when seeking information.

3. To measure the frequency of the library visits outside the college.

4. To identify the preference-wise sources of information in the research activities.

5. To explore the preferences regarding search engines in seeking information.

6. To evaluate the role of the libraries and information centres in providing information to the college teachers. 


\section{Review of the Literature and Development of the Subject}

The scientific research regarding the information seeking behaviour dates back to the 1940s. After that, a considerable volume of literature has been published, dealing with the information needs and seeking patterns of library users. A great deal of research has also focused in the analysis of the information seeking behaviour of the library users, irrespective of the types of their occupations and fields of study. The information seeking behaviour of the academic community has been an important area of current research.

An important work has been carried out by Watson, Blakeley and Abbott (1988) on the use of communication technologies in teacher education. The results show that the teachers' educators are inexperienced in the use of ICT. This ignorance could be party attributed to the university computer networks staff failure to understand the users' needs of distribution and distance networks.

Sethi (1990), one of the eminent research scholars, has surveyed social scientists in his attempt to identify the particular characteristics of their information seeking behaviour. The study reveals that the academic staff prefers mostly journals as sources of information, followed by books, seminars and conferences.

The specificities of the information seeking behaviour of professors of Art History and Studio Art have been studied by Jacquelyn Challener (1999). She measures the frequency of library visits of the respondents and identifies the reasons for such visits. She concludes that most of the participants use computers for seeking information. She also finds that the majority use slides extensively in the classroom, supplemented in most cases by textbooks, and also journal articles. Finally, approximately $50 \%$ of the respondents use computers for teaching purposes.

Shanmugam (1999) has investigated the information seeking behaviour of trainee teachers from two teacher training colleges within the state of Johor, Malaysia. The findings reveal that the majority of the trainees' information needs are centred in their course work and there is a low awareness of the existence of information outside their field of study. Additionally, more than half of the trainees moderately expressed positive feelings for seeking information while they mostly preferred informal and interpersonal sources.

Shooken and Kushik (2002) have studied the information seeking behaviour of social scientists, engaged in different universities in Haryana, India. Their findings reveal that most of the social scientists use the library regularly, and they seek information for their research activities through indexing and abstracting periodicals and citations in articles. Obviously, they mostly prefer current journals, followed by books.

Similarly, Lewin and Stokes (2004) have studied the information-seeking behaviour of a group of lecturers, based on one site, delivering a nursing and midwifery curriculum in the School of Health Studies of a higher education institution. The findings show that, in order to access information, lecturers are most likely to visit the institutional libraries, go online, get advice from their 
colleagues and depend on their personal collections. Among the various alternatives, refereed journals are the top ranked information resource, with professional studies and research cited as the most popular topics. What should be noted regarding this study is that lecturers mention the role of the library staff as integral to the information-seeking process.

Suriya, Sangeetha and Nambi (2004) have carried out research on the information seeking behavior of faculty members from Government Arts Colleges in Cuddalore District. The study reveals how faculty members seek information from the library. It concludes that most of the respondents visit the library several times a week to meet their information needs. Regarding the type of search made by the respondents, the most popular method among them is search by subject.

Patitungkho and Despande (2005) analyse the information seeking behaviour of faculty members of the Rajbhat Universities in Bangkok. The study finds that most of the faculty members use text books. Almost all the users also use the internet, seeking information from the library through the Google search engine. They also prefer Thai language for reading purposes and rely on the Education Resources Information Centre database for covering their information needs. Additionally, they face the problem of overload while seeking information.

Rafiq and Ameen (2007) conclude that books are the most preferred information sources for teaching and research, followed by communication with colleagues and friends in the National Textile University, journal articles, reference materials, theses, projects, technical reports, conference papers, review articles, newspapers, indexes, abstracts and bibliographies. The survey also reveals that websites and e-mail portals are highly used electronic services.

Tahir, Mahmood and Shafique (2008) have studied the information seeking behaviour of Humanities teachers. The study finds that consulting with experts in the subject field is the preferred method of getting information, followed by the conversation with colleagues. The most important resource for teaching are the reference books, whereas consultation with knowledgeable persons or experts in the field is the most important source of information for research. Most teachers in the field of humanities get information from their departmental library and display a clear preference for the print media, while they least prefer audiovisual material.

Qureshi, Zafar and Khan (2008) have investigated how the volume of information needed by college students depends on their surrounding environment. It is argued that their cultural and academic background has a positive impact in the effectiveness of information seeking.

An important study has been conducted by Pattanaik and Parida (2008) on the information needs of scientists engaged in different Agricultural Research Institutes of Odisha, India. Their paper indicates that the agriculture scientists are much diversified in the types of the information they seek, the sources they access and the use they make of this information. It also reveals that the library environment is evolving from printed publications to formless data.

Thanuskodi (2009) has stated that the respondents use IT based libraries 
and information centres as sources of information less frequently than printed sources. The survey reveals that e-mail portals are the most compared to other mediums of online communication. It is suggested that librarians should assist the users in familiarizing with the use of IT based resources. Among the present information sources, books and law reports are considered most important.

Ahenkorah-Marfo, Teye and Senyah (2011) have found that the majority of the respondents consulted textbooks for information, while half of them consulted periodicals, and almost all the respondents used the Google search engine to access information on the Internet. The commonest problems faced by the respondents were unavailability of information, being able to access freely only the abstract of a paper instead of the full-text document, and very old textbooks in the library. A detailed review of the literature presented in this section reveals that many studies have been conducted to explore the information needs and seeking behaviors of various groups of people coming from different academic and occupational backgrounds around the world.

\section{Methodology of the Study}

\section{Data Analysis and Interpretation}

The data collected from the respondents of the present survey are analyzed and interpreted using various statistical techniques, descriptive tables and figures being the statistical tool on which the analysis is mostly based.

\section{Demographic Characteristics of the Respondents}

The distribution of the respondents with regard to their demographic features is shown in Table 1 . The study shows that out of the 408 respondents, $10.3 \%$ belong to the age group of $25-34$ years, $37.8 \%$ were aged between 35 and 44 years, $41.7 \%$ belong to the age group of $45-54$ years and $10.3 \%$ are older than 55 years. Regarding the gender distribution, $54.4 \%$ of them are males and $45.6 \%$ females. Out of the TTC teachers $53.1 \%$ are males, whereas $46.9 \%$ are females. The gender distribution is also similar in the case of the GDC teachers, with $54.5 \%$ of them being males and $45.5 \%$ females.

The survey reveals that 46 respondents have M.Phil qualifications (44 in GDCs and 2 in TTCs) while 146 of them have completed $\mathrm{PhD}$, specifically 131 in GDCs and 15 in TTCs. The rest 47 respondents have other qualifications (43 in GDCs, 4 in TTCs). Of the 408 respondents, 150 (36.8\%) have majored in Arts, 200 (49\%) in Science and 58 (14.2\%) come from Commerce disciplines. With regard to experience, 125 respondents $(30.6 \%)$ have been teaching 1 to 10 years, $241(59 \%)$ have experience ranging from 11 to 20 years while the rest of them (42 respondents, $10.3 \%$ ) have experience of more than 20 years. 
Table 1. Distribution of the Respondents by Demographic Attributes

\begin{tabular}{|l|l|c|c|c|c|c|c|}
\hline Variables & & \multicolumn{2}{|c|}{ Training College } & \multicolumn{2}{c|}{ Degree College } & \multicolumn{2}{c|}{ Total } \\
\hline \multirow{4}{*}{ Sex } & & $f$ & $\%$ & $f$ & $\%$ & $f$ & $\%$ \\
\cline { 2 - 8 } & Male & 17 & 53.1 & 205 & 54.5 & 222 & 54.4 \\
\cline { 2 - 8 } & Female & 15 & 46.9 & 171 & 45.5 & 186 & 45.6 \\
\cline { 2 - 8 } & Total & $\mathbf{3 2}$ & $\mathbf{1 0 0}$ & $\mathbf{3 7 6}$ & $\mathbf{1 0 0}$ & $\mathbf{4 0 8}$ & $\mathbf{1 0 0}$ \\
\hline \multirow{5}{*}{ Age } & $\mathbf{2 5 - 3 4}$ & 0 & - & 42 & 11.2 & 42 & 10.3 \\
\cline { 2 - 8 } & $\mathbf{3 5 - 4 4}$ & 18 & 56.3 & 136 & 36.2 & 154 & 37.8 \\
\cline { 2 - 8 } & $\mathbf{4 5 - 5 4}$ & 12 & 37.5 & 158 & 42 & 170 & 41.7 \\
\cline { 2 - 8 } & $\mathbf{5 5}$ & 2 & 6.3 & 40 & 10.6 & 42 & 10.3 \\
\cline { 2 - 8 } Qualification & Total & $\mathbf{3 2}$ & $\mathbf{1 0 0}$ & $\mathbf{3 7 6}$ & $\mathbf{1 0 0}$ & $\mathbf{4 0 8}$ & $\mathbf{1 0 0}$ \\
\hline \multirow{4}{*}{ Discipline } & M. Phil & 2 & 6.3 & 44 & 11.7 & 46 & 11.3 \\
\cline { 2 - 8 } & Ph.D & 15 & 46.9 & 131 & 34.8 & 146 & 35.8 \\
\cline { 2 - 8 } & Others & 4 & 12.5 & 43 & 11.4 & 47 & 11.5 \\
\cline { 2 - 8 } & Arts & 13 & 40.6 & 137 & 36.4 & 150 & 36.8 \\
\cline { 2 - 8 } & Science & 18 & $\mathbf{5 6 . 3}$ & 182 & 48.4 & 200 & 49 \\
\cline { 2 - 8 } & Commerce & 1 & 3.1 & 57 & 15.2 & 58 & 14.2 \\
\cline { 2 - 8 } & Total & $\mathbf{3 2}$ & $\mathbf{1 0 0}$ & $\mathbf{3 7 6}$ & $\mathbf{1 0 0}$ & $\mathbf{4 0 8}$ & $\mathbf{1 0 0}$ \\
\hline \multirow{5}{*}{ Experience } & $\mathbf{0 - 1 0}$ & 16 & $\mathbf{5 0}$ & 109 & 29 & 125 & 30.6 \\
\cline { 2 - 8 } & $\mathbf{1 1 - 2 0}$ & 11 & 34.4 & 230 & 61.2 & 241 & 59 \\
\cline { 2 - 8 } & $\mathbf{2 0}$ & 5 & 15.6 & 37 & 9.8 & 42 & 10.3 \\
\cline { 2 - 8 } & Total & $\mathbf{3 2}$ & $\mathbf{1 0 0}$ & $\mathbf{3 7 6}$ & $\mathbf{1 0 0}$ & $\mathbf{4 0 8}$ & $\mathbf{1 0 0}$ \\
\hline
\end{tabular}

Source: Author's estimations.

\section{Designation-Wise Distribution of the Respondents}

Table 2 shows that out of the 408 respondents, 169 are Senior Assistant Professors (163 from GDCs, 6 from TTCs), 86 are Assistant Professors (75 from GDCs, 11 from TTCs), 114 are Associate Professors (105 from GDCs, 9 from TTCs) and 39 are Principals (33 from GDCs, 6 from TTCs).

Table 2. Distribution of the Respondents with regard to their Designation

\begin{tabular}{|c|c|c|c|c|c|c|c|c|}
\hline \multirow{2}{*}{ Designation } & \multicolumn{3}{|c|}{ Degree College } & \multicolumn{3}{|c|}{ Training College } & \multicolumn{2}{|c|}{ Total (\%) } \\
\hline & Male & Female & Total & Male & Female & Total & GDCs & $T T C s$ \\
\hline $\begin{array}{r}\text { Assist. Prof. } \\
\underset{\%}{f}\end{array}$ & $\begin{array}{c}46 \\
12.2\end{array}$ & $\begin{array}{l}29 \\
7.7\end{array}$ & $\begin{array}{c}75 \\
20.0\end{array}$ & $\begin{array}{c}7 \\
21.9\end{array}$ & $\begin{array}{c}4 \\
12.5\end{array}$ & $\begin{array}{c}11 \\
344\end{array}$ & 368 & 632 \\
\hline $\begin{array}{r}\text { Sn. As. Prof. } \\
f \\
\%\end{array}$ & $\begin{array}{c}86 \\
22.9\end{array}$ & $\begin{array}{c}77 \\
20.5\end{array}$ & $\begin{array}{c}163 \\
43.4\end{array}$ & $\begin{array}{c}2 \\
6.3\end{array}$ & $\begin{array}{c}4 \\
12.5\end{array}$ & $\begin{array}{c}6 \\
18.8\end{array}$ & 69.8 & 30.2 \\
\hline $\begin{array}{r}\text { Assoc. Prof. } \\
\underset{\%}{f}\end{array}$ & $\begin{array}{c}54 \\
14.4 \\
\end{array}$ & $\begin{array}{c}51 \\
13.6 \\
\end{array}$ & $\begin{array}{c}105 \\
27.9 \\
\end{array}$ & $\begin{array}{c}5 \\
15.6 \\
\end{array}$ & $\begin{array}{c}4 \\
12.5 \\
\end{array}$ & $\begin{array}{c}9 \\
28.1\end{array}$ & 49.8 & 50.2 \\
\hline $\begin{array}{r}\text { Principal } \\
\qquad \underset{\%}{f}\end{array}$ & $\begin{array}{c}29 \\
7.7\end{array}$ & $\begin{array}{c}4 \\
1.1\end{array}$ & $\begin{array}{c}33 \\
8.8\end{array}$ & $\begin{array}{c}5 \\
15.6\end{array}$ & $\begin{array}{c}1 \\
3.1\end{array}$ & $\begin{array}{c}6 \\
18.8\end{array}$ & 31.9 & 68.1 \\
\hline
\end{tabular}

Source: Author's estimations. 


\section{Nature of Information Needs}

The college teachers need to acquire various types of information pertaining to different tasks related to their field, ranging from preparing class lectures to research activities. This diversity of the teachers' information needs is depicted in Table 3. When teachers were asked to report the nature of their information needs, it was revealed that the majority of the respondents of the GDCs $(80.6 \%)$ require information on preparing class lectures with $41.2 \%$ of them characterizing this task as very important, $29.8 \%$ as important and $9.6 \%$ as somewhat important. The second most frequent motive for information seeking is being updated regarding the latest developments of the concerned subject $(73.9 \%$ of the respondents reported that this was the basic reason for searching for information), $21.8 \%$ of those respondents characterize such subject updates as very important, $32.7 \%$ as important and $19.4 \%$ as somewhat important. In descending order, other reasons inducing the teachers to look for information include writing books or articles (63\%), being updated regarding government orders about job openings $(54.8 \%)$, carrying out research $(50.3 \%)$, learning about new conferences or seminars (46.5\%), familiarising with service conditions and rules (44.4\%), being cognizant of the developments of current affairs (44.1\%) and buying teaching or research related computer software (43.9\%). Others kinds of information are also sought by the teachers of the GDCs but very rarely.

As compared to the GDCs, the information seeking behaviour of the respondents of the TTCs was found to be different to some extent. Table 3 shows that most of the respondents $(90.6 \%)$ teaching at training institutes need to get informed on educational software, like Computer Assisted Instructions (CAIs), Web Based Instructions and e-learning, with $68.8 \%$ characterizing it as very important, $18.8 \%$ as important and $3.12 \%$ as somewhat important. The second in order motivation for information seeking is related to research activities. $87.5 \%$ of the respondents stated that they are primarily looking for information regarding the research projects that they conduct, $50 \%$ of them said that this activity is very important while for $25 \%$ of them is just, important and for the rest $12.5 \%$ is somewhat important. As far as the tasks of both writing books and articles and getting updates regarding the latest developments in the field are concerned, it was revealed that $84.4 \%$ of the TTC teachers require information on both of them in a similar pattern. However, the distribution of the tasks is different, compared to the case of the GDC teachers: i) $37.5 \%$ of the respondents rate the task of writing books/articles as very important, $28.1 \%$ opine that it is important and $18.8 \%$ describe it as somewhat important, whereas ii) regarding the updates on the latest developments in the field, $59.4 \%$ of the respondents claimed it is very important, $18.8 \%$ rated it as important, and only $6.3 \%$ respondents mentioned that it is just somewhat important. Among the surveyed TTC respondents, $81.3 \%$ look for paper presentations in seminars or conferences, $65.6 \%$ of them reporting that this activity is very important, $9.4 \%$ important, and $6.3 \%$ just somewhat important. Similar to the case of the DGC teachers, the TTC teachers are also interested in other types of information but they do not consider them as important as the information pieces related to the above tasks and activities. 
Vol. 2, No. $3 \quad$ Kundu: Nature of the Information Seeking Behaviour of Teachers...

Table 3. Distribution of the Respondents by Nature of Information Needs

\begin{tabular}{|c|c|c|c|c|c|c|c|c|}
\hline \multirow{2}{*}{$\begin{array}{l}\text { Nature of information } \\
\text { needs }\end{array}$} & \multicolumn{4}{|c|}{ Degree College } & \multicolumn{4}{|c|}{ Training College } \\
\hline & 3 & 2 & 1 & Total & 3 & 2 & 1 & Total \\
\hline $\begin{array}{l}\text { Preparing class lect. } \\
\qquad \underset{\%}{f}\end{array}$ & $\begin{array}{l}36 \\
9.6\end{array}$ & $\begin{array}{r}112 \\
29.8\end{array}$ & $\begin{array}{l}155 \\
41.2\end{array}$ & $\begin{array}{c}303 \\
80.6\end{array}$ & $\begin{array}{c}4 \\
12.5\end{array}$ & $\begin{array}{c}8 \\
25.0\end{array}$ & $\begin{array}{c}11 \\
34.4\end{array}$ & $\begin{array}{c}23 \\
71.9\end{array}$ \\
\hline $\begin{array}{r}\text { Writing book/articles } \\
\underset{\%}{f}\end{array}$ & $\begin{array}{l}37 \\
9.8\end{array}$ & $\begin{array}{c}63 \\
16.8 \\
\end{array}$ & $\begin{array}{l}137 \\
36.4\end{array}$ & $\begin{array}{c}237 \\
63 \\
\end{array}$ & $\begin{array}{c}6 \\
18.8 \\
\end{array}$ & $\begin{array}{c}9 \\
28.1\end{array}$ & $\begin{array}{c}12 \\
37.5\end{array}$ & $\begin{array}{c}27 \\
84.4\end{array}$ \\
\hline Current affairs & $\begin{array}{c}71 \\
18.9\end{array}$ & $\begin{array}{c}53 \\
14.1\end{array}$ & $\begin{array}{c}42 \\
11.2\end{array}$ & $\begin{array}{l}166 \\
44.1\end{array}$ & $\begin{array}{c}9 \\
28.1\end{array}$ & $\begin{array}{c}4 \\
12.5\end{array}$ & $\begin{array}{c}7 \\
21.9\end{array}$ & $\begin{array}{c}20 \\
62.5\end{array}$ \\
\hline Research work & $\begin{array}{l}25 \\
6.7\end{array}$ & $\begin{array}{c}62 \\
16.5 \\
\end{array}$ & $\begin{array}{c}102 \\
27.1\end{array}$ & $\begin{array}{l}189 \\
50.3\end{array}$ & $\begin{array}{c}4 \\
12.5\end{array}$ & $\begin{array}{c}8 \\
25 \\
\end{array}$ & $\begin{array}{l}16 \\
50\end{array}$ & $\begin{array}{c}28 \\
87.5\end{array}$ \\
\hline Health & $\begin{array}{l}27 \\
7.2 \\
\end{array}$ & $\begin{array}{l}33 \\
8.8 \\
\end{array}$ & $\begin{array}{l}21 \\
5.6 \\
\end{array}$ & $\begin{array}{c}81 \\
21.5 \\
\end{array}$ & $\begin{array}{c}4 \\
12.5 \\
\end{array}$ & $\begin{array}{c}7 \\
21.9 \\
\end{array}$ & $\begin{array}{c}2 \\
6.3 \\
\end{array}$ & $\begin{array}{c}13 \\
40.6 \\
\end{array}$ \\
\hline Workshop/Seminar & $\begin{array}{l}18 \\
4.8\end{array}$ & $\begin{array}{c}50 \\
13.3\end{array}$ & $\begin{array}{r}107 \\
28.5\end{array}$ & $\begin{array}{c}175 \\
46.5\end{array}$ & $\begin{array}{c}2 \\
6.3\end{array}$ & $\begin{array}{c}3 \\
9.4\end{array}$ & $\begin{array}{c}21 \\
65.6\end{array}$ & $\begin{array}{c}26 \\
81.3\end{array}$ \\
\hline Entertainment & $\begin{array}{c}50 \\
13.3 \\
\end{array}$ & $\begin{array}{c}30 \\
8\end{array}$ & $\begin{array}{l}16 \\
4.3 \\
\end{array}$ & $\begin{array}{c}96 \\
25.5\end{array}$ & $\begin{array}{c}7 \\
21.9 \\
\end{array}$ & $\begin{array}{c}5 \\
15.6 \\
\end{array}$ & $\begin{array}{c}5 \\
15.6 \\
\end{array}$ & $\begin{array}{c}17 \\
53.1\end{array}$ \\
\hline $\begin{array}{lr}\text { Latest Development } & f \\
& \boldsymbol{\%} \\
\end{array}$ & $\begin{array}{c}73 \\
19.4\end{array}$ & $\begin{array}{l}123 \\
32.7\end{array}$ & $\begin{array}{c}82 \\
21.8 \\
\end{array}$ & $\begin{array}{l}278 \\
73.9\end{array}$ & $\begin{array}{c}2 \\
6.3 \\
\end{array}$ & $\begin{array}{c}6 \\
18.8 \\
\end{array}$ & $\begin{array}{c}19 \\
59.4\end{array}$ & $\begin{array}{c}27 \\
84.4\end{array}$ \\
\hline Syllabus & $\begin{array}{c}90 \\
23.9\end{array}$ & $\begin{array}{c}46 \\
12.2 \\
\end{array}$ & $\begin{array}{l}22 \\
5.9\end{array}$ & $\begin{array}{l}158 \\
42.0\end{array}$ & $\begin{array}{c}1 \\
3.1 \\
\end{array}$ & $\begin{array}{c}5 \\
15.6 \\
\end{array}$ & $\begin{array}{c}8 \\
25 \\
\end{array}$ & $\begin{array}{c}14 \\
43.8 \\
\end{array}$ \\
\hline $\begin{array}{r}f \\
\%\end{array}$ & $\begin{array}{l}21 \\
5.6\end{array}$ & $\begin{array}{l}21 \\
5.6\end{array}$ & $\begin{array}{c}13 \\
3.5\end{array}$ & $\begin{array}{c}55 \\
14.6 \\
\end{array}$ & $\begin{array}{c}2 \\
6.3\end{array}$ & $\begin{array}{c}4 \\
12.5\end{array}$ & $\begin{array}{c}3 \\
9.4\end{array}$ & $\begin{array}{c}9 \\
28.1\end{array}$ \\
\hline Computer Software $f$ & $\begin{array}{c}30 \\
8\end{array}$ & $\begin{array}{c}69 \\
18.4\end{array}$ & $\begin{array}{c}66 \\
17.6\end{array}$ & $\begin{array}{l}165 \\
43.9\end{array}$ & $\begin{array}{c}2 \\
6.6\end{array}$ & $\begin{array}{c}5 \\
15.2\end{array}$ & $\begin{array}{c}1 \\
3.1\end{array}$ & $\begin{array}{c}8 \\
25 \\
\end{array}$ \\
\hline \begin{tabular}{|c} 
Administrative jobs \\
$\underset{\%}{f}$
\end{tabular} & $\begin{array}{c}30 \\
8 \\
\end{array}$ & $\begin{array}{c}48 \\
12.8 \\
\end{array}$ & $\begin{array}{r}13 \\
3.5 \\
\end{array}$ & $\begin{array}{c}91 \\
24.2\end{array}$ & $\begin{array}{c}3 \\
9.4\end{array}$ & $\begin{array}{c}5 \\
15.6 \\
\end{array}$ & $\begin{array}{c}2 \\
6.3\end{array}$ & $\begin{array}{c}10 \\
31.3\end{array}$ \\
\hline $\begin{array}{l}\text { Educational software } \\
\text { (CAI,WBI,e-learning) } \\
\\
\%\end{array}$ & $\begin{array}{c}42 \\
11.2\end{array}$ & $\begin{array}{l}20 \\
5.3\end{array}$ & $\begin{array}{l}16 \\
4.3\end{array}$ & $\begin{array}{c}78 \\
20.7\end{array}$ & $\begin{array}{c}1 \\
3.12\end{array}$ & $\begin{array}{c}6 \\
18.8\end{array}$ & $\begin{array}{c}22 \\
68.8\end{array}$ & $\begin{array}{c}29 \\
90.6\end{array}$ \\
\hline Professional Assoc. & $\begin{array}{l}21 \\
5.6\end{array}$ & $\begin{array}{c}59 \\
15.7\end{array}$ & $\begin{array}{c}54 \\
14.4\end{array}$ & $\begin{array}{c}134 \\
35.6\end{array}$ & $\begin{array}{c}3 \\
9.4\end{array}$ & $\begin{array}{c}4 \\
12.5\end{array}$ & $\begin{array}{c}4 \\
12.5\end{array}$ & $\begin{array}{c}11 \\
34.4\end{array}$ \\
\hline Service rules & $\begin{array}{c}44 \\
11.7\end{array}$ & $\begin{array}{c}46 \\
12.2 \\
\end{array}$ & $\begin{array}{c}77 \\
20.5\end{array}$ & $\begin{array}{r}167 \\
44.4 \\
\end{array}$ & $\begin{array}{c}5 \\
15.6 \\
\end{array}$ & $\begin{array}{c}4 \\
12.5 \\
\end{array}$ & $\begin{array}{c}9 \\
28.1 \\
\end{array}$ & $\begin{array}{c}18 \\
56.3\end{array}$ \\
\hline $\begin{array}{l}\text { Govt. orders regarding } \\
\text { jobs } \\
\qquad \begin{array}{c}f \\
\%\end{array}\end{array}$ & $\begin{array}{c}30 \\
8\end{array}$ & $\begin{array}{c}66 \\
17.6\end{array}$ & $\begin{array}{l}110 \\
29.3\end{array}$ & $\begin{array}{l}206 \\
54.8\end{array}$ & $\begin{array}{c}6 \\
18.8\end{array}$ & $\begin{array}{c}6 \\
18.8\end{array}$ & $\begin{array}{c}9 \\
28.1\end{array}$ & $\begin{array}{c}21 \\
65.6\end{array}$ \\
\hline
\end{tabular}

Note: 1=Very Important; 2=Important; 3=Somewhat Important.

Source: Author's estimations. 
Similar comparisons between the GDCs and TTCs could also be made possible regarding the nature of their seeking behaviour when it comes to acquiring information on professional associations, syllabus, health, current affairs, entertainment, administrative work, educational software, etc. Based on the present data analysis, it can be inferred that the TTC teachers are more engaged in research, thus more frequently writing books and articles than the GDC ones.

\section{Use of Formal Information Sources}

The college teachers use different information sources (both formal and informal) to meet their required information. The opinion of the respondents concerning this issue is presented in Table 4. The data reveals that most of the respondents $(89.4 \%)$ teaching at GDCs use journals as their primary information source, $71.5 \%$ of them report a frequent usage, $13.8 \%$ an occasional one and $4 \%$ said that they are just rarely using it. On the other hand, the text books $(93.8 \%)$ are used mostly by the teachers of Training Colleges, $71.9 \%$ of them mention that they use them frequently, $15.6 \%$ point out an occasional usage and $6.3 \%$ report a rare usage. The data also reveal that the use of reference books is the second most popular information source $(83.8 \%)$ among the GDC teachers, being used frequently by $58.2 \%$ of them, occasionally by $17 \%$, and rarely by $8.5 \%$. On the contrary, the teachers of the Training Colleges often use research reports as their basic formal information source $(84.4 \%), 53.1 \%$ of those who reported such reports as the primary means of information refer to them frequently, $18.8 \%$ occasionally and $12.5 \%$ rarely, followed by electronic databases (81.3\%). Based on the analysis discussed above, it can be inferred that the General Degree College teachers heavily depend on journals and reference books for getting informed, whereas the Teachers' Training College teachers depend on text books, research reports and electronic databases. The other important sources, that GDC teachers consult in order to cover their teaching and research needs, are newspapers $(74.7 \%)$, text books $(65.7 \%)$, conference papers $(55.6 \%)$, research reports $(52.7 \%)$, and book reviews $(45.7 \%)$. The use of government publications (28.7\%), lectures notes $(27.7 \%)$, encyclopedias (24.2\%), electronic databases (19.4\%), library catalogues (14.4\%), and bibliographies $(13.6 \%)$ are recorded in low frequency. In the case of the Teachers' Training Colleges, $78.1 \%$ of the respondents use newspapers to seek information, while the second most popular source are conference papers $(71.9 \%)$. Almost $70 \%$ of the Training College teachers report that they refer to bibliographies as a basic informational source, $31.3 \%$ of them mentioned that they use it frequently, $21.9 \%$ use it occasionally and $15.6 \%$ use it rarely. Additionally, the use of journals and book reviews is rather moderate $(46.9 \%)$, the reference books $(43.8 \%)$, indexes $(40.6 \%)$, and government publications $(37.5 \%)$ following with descending order in their preferences. The respondents mentioned the use of others sources, also for seeking information, but only exceptionally. 
Vol. 2, No. $3 \quad$ Kundu: Nature of the Information Seeking Behaviour of Teachers...

Table 4. Distribution of the Respondents by Usage of Formal Information Sources

\begin{tabular}{|c|c|c|c|c|c|c|c|c|}
\hline \multirow{2}{*}{$\begin{array}{l}\text { Use of formal } \\
\text { information } \\
\text { sources }\end{array}$} & \multicolumn{4}{|c|}{ Degree College } & \multicolumn{4}{|c|}{ Training College } \\
\hline & 3 & 2 & 1 & Total & 3 & 2 & 1 & Total \\
\hline \multicolumn{9}{|l|}{ Book reviews } \\
\hline$\underset{\sigma}{f}$ & 37 & 88 & 47 & 172 & 8 & 3 & 4 & 15 \\
\hline \multicolumn{9}{|l|}{ Encyclopedias } \\
\hline$f$ & 16 & 33 & 42 & 91 & 1 & 4 & 6 & 11 \\
\hline$\%$ & 4.3 & 8.8 & 11.2 & 24.2 & 3.1 & 12.5 & 18.8 & 34.4 \\
\hline \multicolumn{9}{|l|}{ Newspaper } \\
\hline$f$ & 75 & 95 & 111 & 281 & 4 & 8 & 13 & 25 \\
\hline$\%$ & 19.9 & 25.3 & 29.5 & 74.7 & 12.5 & 25 & 40.6 & 78.1 \\
\hline \multicolumn{9}{|l|}{$\begin{array}{l}\text { Conference/ } \\
\text { Seminar paper }\end{array}$} \\
\hline & 45 & 73 & 91 & 209 & 4 & 7 & 12 & 23 \\
\hline$\%$ & 12 & 19.4 & 24.2 & 55.6 & 12.5 & 21.9 & 37.5 & 71.9 \\
\hline \multicolumn{9}{|l|}{ Index/Abstracts } \\
\hline & 32 & 23 & 17 & 72 & 6 & 5 & 2 & 13 \\
\hline$\%$ & 8.5 & 6.2 & 4.5 & 19.2 & 18.8 & 15.6 & 6.3 & 40.6 \\
\hline \multicolumn{9}{|l|}{ Bibliographies } \\
\hline$f$ & 29 & 14 & 8 & 51 & 5 & 7 & 10 & 22 \\
\hline$\%$ & 7.7 & 3.7 & 2.1 & 13.6 & 15.6 & 21.9 & 31.3 & 68.8 \\
\hline \multicolumn{9}{|l|}{ Electronic DB } \\
\hline & 34 & 21 & 18 & 73 & 3 & 4 & 19 & 26 \\
\hline$\%$ & 9 & 5.6 & 4.8 & 19.4 & 9.37 & 12.5 & 59.4 & 81.3 \\
\hline \multicolumn{9}{|l|}{ Lecture notes } \\
\hline$f$ & 26 & 37 & 41 & 104 & 4 & 3 & 1 & 8 \\
\hline$\%$ & 6.9 & 9.8 & 10.9 & 27.7 & 12.5 & 9.37 & 3.1 & 25 \\
\hline \multicolumn{9}{|l|}{$\begin{array}{l}\text { Research } \\
\text { report }\end{array}$} \\
\hline Pora & 29 & 76 & 93 & 198 & 4 & 6 & 17 & 27 \\
\hline$\%$ & 7.7 & 20.2 & 27.4 & 52.7 & 12.5 & 18.8 & 53.1 & 84.4 \\
\hline \multicolumn{9}{|l|}{ Textbooks } \\
\hline 年 & 58 & 79 & 110 & 247 & 2 & 5 & 23 & 30 \\
\hline$\%$ & 15.4 & 21 & 29.3 & 65.7 & 6.3 & 15.6 & 71.9 & 93.8 \\
\hline \multicolumn{9}{|l|}{ Reference book } \\
\hline$f$ & 32 & 64 & 219 & 315 & 5 & 3 & 6 & 14 \\
\hline$\%$ & 8.5 & 17.0 & 58.2 & 83.8 & 15.6 & 9.4 & 18.8 & 43.8 \\
\hline \multicolumn{9}{|l|}{ Journals } \\
\hline$f$ & 15 & 52 & 269 & 336 & 5 & 6 & 4 & 15 \\
\hline$\%$ & 4.0 & 13.8 & 71.5 & 89.4 & 15.6 & 18.8 & 12.5 & 46.9 \\
\hline \multicolumn{9}{|l|}{$\begin{array}{l}\text { Library } \\
\text { catalog. }\end{array}$} \\
\hline o & 27 & 16 & 11 & 54 & 3 & 2 & 2 & 7 \\
\hline$\%$ & 7.2 & 4.3 & 2.9 & 14.4 & 9.37 & 6.3 & 6.3 & 21.9 \\
\hline \multicolumn{9}{|l|}{$\begin{array}{l}\text { Governmental } \\
\text { Publications }\end{array}$} \\
\hline$\underset{\sigma}{f}$ & 37 & 44 & 27 & 108 & 4 & 3 & 5 & 12 \\
\hline$\%$ & 9.8 & 11.7 & 7.2 & 28.7 & 12.5 & 9.4 & 15.6 & 37.5 \\
\hline
\end{tabular}

Note: 1=Frequently; 2=Occasionally; 3=Rarely.

Source: Author's estimations. 


\section{Use of Informal Information Sources}

In the context of the survey, respondents were also provided with a list of informal sources, presented in Table 5. The data shows that the teachers of the GDCs opted for the internet newsgroup as the most preferred source of information $(81.9 \%$ ), with $46.8 \%$ of them indicating a frequent usage, $17.8 \%$ an occasional one and $17.3 \%$ saying that they only refer to it rarely. Attending workshops or training seminars $(71.3 \%)$ is ranked as the second in order of importance source of information, with $33.2 \%$ of the teachers reporting a frequent use, $23.4 \%$ referring to it occasionally, and $14.6 \%$ only rarely. The survey also reveals other important information sources such as colleagues (56.4\%), TV/FM radio (55.9\%), and subject experts (49.5\%). Friends (43.6\%), family members $(32.5 \%)$ and book store websites $(24.5 \%)$ are moderately used by the GDC teachers as informal information sources. When asked about the use of book store websites as a potential source of information, the data show that $7.7 \%$ of the respondents use them frequently, $5.9 \%$ used them occasionally and $10.9 \%$ used them rarely to fulfill their information needs. Only $20.5 \%$ of the GDC teachers contact the librarians for acquiring a specific piece of information, $8.8 \%$ of them reported a frequent consultation, $5.6 \%$ consulted the librarian occasionally, and $6.1 \%$ rarely.

The analysis shows that the majority of the TTC respondents discussed with their colleagues (93.8\%), 50\% of them discussed frequently, 31.3\% occasionally and $12.5 \%$ discussed rarely. There is also a strong preference for workshop/attending training courses among them $(84.4 \%)$ with $43.8 \%$ of them attending frequently, $21.9 \%$ occasionally and $18.8 \%$ only rarely. Television and radio, preferred by a share of $65.6 \%$ of the respondents, are used frequently by $43.8 \%$ of them, occasionally by $15.6 \%$, and rarely by a share of $6.3 \%$. The subject experts consultation resorted to by $62.5 \%$ of the surveyed teachers, is a frequent activity for $18.8 \%$ of the respondents, an occasional one for $21.9 \%$ and just a rare activity for the rest. What should be highlighted is the fact that the $59.4 \%$ of TTC teachers discuss with their own institutions' librarians, with $34.4 \%$ of them meeting them frequently, $18.8 \%$ occasionally, and $6.3 \%$ rarely. Other sources such as book store websites (46.9\%), family members $(37.5 \%)$, friends $(31.3 \%)$, and internet newsgroups $(28.1 \%)$ also serve as informal information sources. 
Table 5. Distribution of the Respondents by Usage of Informal Information Sources

\begin{tabular}{|c|c|c|c|c|c|c|c|c|}
\hline \multirow{2}{*}{ Use of Informal Sources } & \multicolumn{4}{|c|}{ Degree College } & \multicolumn{4}{|c|}{ Training College } \\
\hline & 3 & 2 & 1 & Total & 3 & 2 & 1 & Total \\
\hline Subject experts & $\begin{array}{c}46 \\
12.2 \\
\end{array}$ & $\begin{array}{c}77 \\
20.5 \\
\end{array}$ & $\begin{array}{c}63 \\
16.8 \\
\end{array}$ & $\begin{array}{r}186 \\
49.5 \\
\end{array}$ & $\begin{array}{c}7 \\
21.9 \\
\end{array}$ & $\begin{array}{c}7 \\
21.9 \\
\end{array}$ & $\begin{array}{c}6 \\
18.8 \\
\end{array}$ & $\begin{array}{c}20 \\
62.5 \\
\end{array}$ \\
\hline Librarians & $\begin{array}{l}23 \\
6.1 \\
\end{array}$ & $\begin{array}{l}21 \\
5.6 \\
\end{array}$ & $\begin{array}{r}33 \\
8.8 \\
\end{array}$ & $\begin{array}{c}77 \\
20.5 \\
\end{array}$ & $\begin{array}{c}2 \\
6.3 \\
\end{array}$ & $\begin{array}{c}6 \\
18.8 \\
\end{array}$ & $\begin{array}{c}11 \\
34.4 \\
\end{array}$ & $\begin{array}{c}19 \\
59.4\end{array}$ \\
\hline Colleagues & $\begin{array}{c}50 \\
13.3 \\
\end{array}$ & $\begin{array}{c}68 \\
18.1 \\
\end{array}$ & $\begin{array}{l}94 \\
25 \\
\end{array}$ & $\begin{array}{c}212 \\
56.4\end{array}$ & $\begin{array}{c}4 \\
12.5 \\
\end{array}$ & $\begin{array}{c}10 \\
31.3 \\
\end{array}$ & $\begin{array}{c}16 \\
50.0\end{array}$ & $\begin{array}{c}30 \\
93.8 \\
\end{array}$ \\
\hline TV/Radio & $\begin{array}{c}92 \\
24.5 \\
\end{array}$ & $\begin{array}{c}70 \\
18.6 \\
\end{array}$ & $\begin{array}{c}48 \\
12.8 \\
\end{array}$ & $\begin{array}{r}210 \\
55.9 \\
\end{array}$ & $\begin{array}{c}2 \\
6.3 \\
\end{array}$ & $\begin{array}{c}5 \\
15.6 \\
\end{array}$ & $\begin{array}{c}14 \\
43.8 \\
\end{array}$ & $\begin{array}{c}21 \\
65.6 \\
\end{array}$ \\
\hline Friends & $\begin{array}{c}39 \\
10.4\end{array}$ & $\begin{array}{c}56 \\
14.9\end{array}$ & $\begin{array}{c}69 \\
18.4\end{array}$ & $\begin{array}{c}164 \\
43.6\end{array}$ & $\begin{array}{c}5 \\
15.6\end{array}$ & $\begin{array}{c}2 \\
6.3 \\
\end{array}$ & $\begin{array}{c}3 \\
9.37\end{array}$ & $\begin{array}{c}10 \\
31.3\end{array}$ \\
\hline Family member & $\begin{array}{c}52 \\
13.8 \\
\end{array}$ & $\begin{array}{c}41 \\
10.9 \\
\end{array}$ & $\begin{array}{r}29 \\
7.7 \\
\end{array}$ & $\begin{array}{r}122 \\
32.5 \\
\end{array}$ & $\begin{array}{c}2 \\
6.3 \\
\end{array}$ & $\begin{array}{c}4 \\
12.5 \\
\end{array}$ & $\begin{array}{c}6 \\
18.8 \\
\end{array}$ & $\begin{array}{c}12 \\
37.5 \\
\end{array}$ \\
\hline Internet Newsgroup & $\begin{array}{c}65 \\
17.3\end{array}$ & $\begin{array}{c}67 \\
17.8\end{array}$ & $\begin{array}{l}176 \\
46.8\end{array}$ & $\begin{array}{c}308 \\
81.9\end{array}$ & $\begin{array}{c}5 \\
15.6\end{array}$ & $\begin{array}{c}1 \\
3.1\end{array}$ & $\begin{array}{c}3 \\
9.37 \\
\end{array}$ & $\begin{array}{c}9 \\
28.1\end{array}$ \\
\hline Bookstore Websites & $\begin{array}{c}41 \\
10.9 \\
\end{array}$ & $\begin{array}{l}22 \\
5.9 \\
\end{array}$ & $\begin{array}{r}29 \\
7.7 \\
\end{array}$ & $\begin{array}{c}92 \\
24.5 \\
\end{array}$ & $\begin{array}{c}7 \\
21.8 \\
\end{array}$ & $\begin{array}{c}6 \\
18.8 \\
\end{array}$ & $\begin{array}{c}2 \\
6.5 \\
\end{array}$ & $\begin{array}{c}15 \\
46.9 \\
\end{array}$ \\
\hline Workshop/ Training & $\begin{array}{c}55 \\
14.6 \\
\end{array}$ & $\begin{array}{c}88 \\
23.4\end{array}$ & $\begin{array}{r}125 \\
33.2 \\
\end{array}$ & $\begin{array}{r}268 \\
71.3 \\
\end{array}$ & $\begin{array}{c}6 \\
18.8 \\
\end{array}$ & $\begin{array}{c}7 \\
21.9 \\
\end{array}$ & $\begin{array}{c}14 \\
43.8\end{array}$ & $\begin{array}{c}27 \\
84.4\end{array}$ \\
\hline
\end{tabular}

Note: 1=Frequently; 2=Occasionally; 3=Rarely.

Source: Author's estimations.

\section{Library Visits for Information Needs}

Respondents are also asked about the frequency of their library visits outside their own institution, in their attempt to acquire information. Table 6 shows that the majority of the respondents $(49.8 \%)$ visit the other libraries frequently, $22.1 \%$ once in a week, $13.3 \%$ once in a month and $11.8 \%$ visit the libraries every day. Only $2.7 \%$ of the whole sample does not visit libraries outside the institutions they belong to at all. 
Table 6. Distribution of the Respondents by Frequency of Library Visits

\begin{tabular}{|l|c|c|c|c|c|c|}
\hline \multirow{2}{*}{ Frequency of visit } & \multicolumn{2}{|c|}{ Degree College } & \multicolumn{2}{c|}{ Training College } & \multicolumn{2}{c|}{ Total } \\
\cline { 2 - 7 } & $\boldsymbol{f}$ & $\mathbf{\%}$ & $\boldsymbol{f}$ & $\boldsymbol{\%}$ & $\boldsymbol{f}$ & $\mathbf{\%}$ \\
\hline Everyday & 45 & 12 & 3 & 9.4 & 48 & 11.8 \\
\hline Once in a Week & 85 & 22.6 & 5 & 15.6 & 90 & 22.1 \\
\hline Once in a Month & 56 & 14.9 & 0 & 0 & 56 & 13.3 \\
\hline Frequently & 180 & 47.9 & 23 & 71.9 & 203 & 49.8 \\
\hline Not at all & 10 & 2.7 & 1 & 3.1 & 11 & 2.7 \\
\hline $\begin{array}{l}\text { Number of respondents } \\
\text { visited the library }\end{array}$ & 366 & 97.3 & 31 & 98.9 & 397 & 97.3 \\
\hline
\end{tabular}

Source: Author's estimations.

\section{Use of Search Engines while Seeking Information}

The college teachers use various search engines for seeking information in their daily life. Respondents were asked to indicate the kinds of search engines through which they seek information. In their majority, the respondents (96.1\%) of both the college types report that they use Google to seek information through internet. The second most popular search engine is Yahoo $(71.6 \%)$ while other search engines are used by $32.2 \%$ of the respondents (Table 7).

Table 7. Distribution of the Respondents by usage of Search Engine in Seeking Information

\begin{tabular}{|c|c|c|c|c|c|c|c|c|c|c|}
\hline \multirow{2}{*}{$\begin{array}{l}\text { Search } \\
\text { engine }\end{array}$} & \multicolumn{4}{|c|}{ Degree College } & \multicolumn{4}{|c|}{ Training College } & \multicolumn{2}{|c|}{ Total } \\
\hline & 1 & 2 & 3 & Total & 1 & 2 & 3 & Total & $f$ & $\%$ \\
\hline 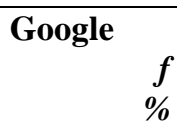 & $\begin{array}{c}288 \\
76.6\end{array}$ & $\begin{array}{c}53 \\
14.1\end{array}$ & $\begin{array}{l}20 \\
5.3\end{array}$ & $\begin{array}{c}361 \\
96\end{array}$ & $\begin{array}{c}23 \\
71.9\end{array}$ & $\begin{array}{c}6 \\
12.5\end{array}$ & $\begin{array}{c}2 \\
6.25\end{array}$ & $\begin{array}{c}31 \\
96.9\end{array}$ & 392 & 96.1 \\
\hline Yahoo & $\begin{array}{c}57 \\
15.2 \\
\end{array}$ & $\begin{array}{r}187 \\
49.7 \\
\end{array}$ & $\begin{array}{l}29 \\
7.7 \\
\end{array}$ & $\begin{array}{c}273 \\
72.6 \\
\end{array}$ & $\begin{array}{c}8 \\
25 \\
\end{array}$ & $\begin{array}{c}7 \\
21.9 \\
\end{array}$ & $\begin{array}{c}4 \\
12.5 \\
\end{array}$ & $\begin{array}{c}19 \\
59.4\end{array}$ & 292 & 71.6 \\
\hline Others & $\begin{array}{l}16 \\
4.3\end{array}$ & $\begin{array}{c}34 \\
9\end{array}$ & $\begin{array}{c}71 \\
18.9\end{array}$ & $\begin{array}{l}121 \\
32.2\end{array}$ & - & $\begin{array}{c}2 \\
6.3\end{array}$ & $\begin{array}{c}6 \\
18.8\end{array}$ & $\begin{array}{c}8 \\
25\end{array}$ & 129 & 32.2 \\
\hline
\end{tabular}

Note: 1=Frequently; 2=Occasionally; 3=Rarely.

Source: Author's estimations.

\section{Preference of Version}

The attitudes of the respondents towards the information format they prefer to refer to has changed. Some respondents prefer the printed version of the documents, others like the electronic version, and some intend to use both. When the respondents of the GDCs were asked to mention which version they prefer, it was revealed that the majority of them $(83.8 \%)$ prefer the printed version, $33.2 \%$ reporting that they have strong preference in hard copies, $49.2 \%$ just a moderate one, and $1.3 \%$ a weak preference (Table 8 ). 
As compared to this, all the respondents of the TTCs indicated the hard copies as their most preferred version of documents. However, electronic documents and audio-visual materials are also equally important to the respondents of both these groups (Table 8).

Table 8. Distribution of the Respondents by Preferred Format of Information Resources

\begin{tabular}{|c|c|c|c|c|c|c|c|c|c|c|}
\hline \multirow{2}{*}{$\begin{array}{l}\text { Format of } \\
\text { information }\end{array}$} & \multicolumn{5}{|c|}{ Degree College } & \multicolumn{5}{|c|}{ Training College } \\
\hline & 1 & 2 & 3 & 4 & Total & 1 & 2 & 3 & 4 & Total \\
\hline \multirow[t]{3}{*}{ Print } & & & & & & & & & & \\
\hline & 125 & 185 & 5 & 61 & 315 & 5 & 25 & 2 & - & 32 \\
\hline & 33.2 & 49.2 & 1.3 & 16.2 & 83.8 & 15.6 & 78.1 & 6.3 & - & 100 \\
\hline \multirow[t]{3}{*}{$\begin{array}{l}\text { Electronic } \\
\text { document }\end{array}$} & & & & & & & & & & \\
\hline & 46 & 126 & 26 & 178 & 198 & 5 & 25 & - & 2 & 30 \\
\hline & 12.2 & 33.5 & 6.9 & 47.3 & 52.7 & 15.6 & 78.1 & - & 6.3 & 93.8 \\
\hline \multirow[t]{3}{*}{$\begin{array}{l}\text { A-V } \\
\text { Materials }\end{array}$} & & & & & & & & & & \\
\hline & 146 & 64 & 36 & 130 & 246 & 3 & 18 & 4 & 7 & 25 \\
\hline & 38.8 & 17.0 & 9.6 & 34.6 & 65.4 & 9.4 & 56.3 & 12.5 & 21.9 & 78.1 \\
\hline
\end{tabular}

Note: $1=$ Most preferred; $2=$ Preferred; $3=$ Less preferred; $4=$ Not preferred.

Source: Author's estimations.

\section{Most Preferred/Useful Sources for Research Work}

In order to get a clear picture of the patterns and trends in information seeking as well as its potential use and value for research the respondents were asked about the sources of information they mostly refer to. Journals are the most preferred sources of information for the teachers of the GDCs (37.8\%), followed by reference books (14.4\%), electronic databases (11.2\%), and subject experts $(9.8 \%)$. Reference books are the most useful sources for the teachers of TTCs $(40.6 \%)$, followed by electronic databases $(21.9 \%)$, journals $(15.6 \%)$ and subject experts (12.5\%) (Table 9).

Table 9. Distribution of the Respondents by Most Preferred Sources of Information in Research

\begin{tabular}{|l|c|c|l|c|c|}
\hline \multirow{2}{*}{$\begin{array}{l}\text { Information sources } \\
\text { (By ordinal value) }\end{array}$} & \multicolumn{2}{|c|}{ GDCs } & Information sources & \multicolumn{2}{c|}{ TTCs } \\
\cline { 2 - 6 } (By ordinal value) & $\boldsymbol{f}$ & $\boldsymbol{\%}$ & $\boldsymbol{f}$ & $\boldsymbol{\%}$ \\
\hline Journals & 142 & 37.8 & Reference books & 13 & 40.6 \\
\hline Reference books & 54 & 14.4 & Electronic databases & 7 & 21.9 \\
\hline Electronic databases & 42 & 11.2 & Journal & 5 & 15.6 \\
\hline Subject experts & 37 & 9.8 & Subject experts & 3 & 12.5 \\
\hline Text books & 30 & 8.0 & Text books & 2 & 6.3 \\
\hline Dissertation/Theses & 27 & 7.2 & Dissertation/Theses & 1 & 3.1 \\
\hline $\begin{array}{l}\text { Proceedings/ } \\
\text { Conference papers }\end{array}$ & 24 & 6.4 & $\begin{array}{l}\text { Proceedings/ } \\
\text { Conference papers }\end{array}$ & 1 & 3.1 \\
\hline Newspapers & 20 & 5.3 & & & \\
\hline
\end{tabular}

Source: Author's estimations. 


\section{Level of Satisfaction about the Libraries}

Perhaps the most important source of information is the library. The majority of the teachers often visit the libraries while many among them have the habit of going there more than once in a week. Thus, the teacher's evaluation of various types of libraries constitutes a significant determinant of their information seeking behaviour. The respondents in each type of college were also asked to rate the level of the satisfaction they get from the services provided by the libraries. The study reveals that only $8 \%$ and $15.6 \%$ of the respondents of the GDCs and TTCs respectively rate the college library as excellent, while the majority of the teachers rate it as good. A big proportion of the respondents use neither the university libraries nor the public libraries. Based on this descriptive analysis, a hypothesis regarding the existence of a significant difference between satisfaction levels acquired by accessing the services of various types of libraries could be formulated (Table 10).

Table 10. Distribution of the Respondents by Evaluation of the Libraries

\begin{tabular}{|c|c|c|c|c|c|c|c|c|}
\hline \multirow[t]{2}{*}{ Types of library } & \multicolumn{4}{|c|}{ Degree College } & \multicolumn{4}{|c|}{ Training College } \\
\hline & 1 & 2 & 3 & 4 & 1 & 2 & 3 & 4 \\
\hline Public library & $\begin{array}{l}20 \\
5.3\end{array}$ & $\begin{array}{r}170 \\
45.2\end{array}$ & $\begin{array}{c}50 \\
13.3\end{array}$ & $\begin{array}{r}136 \\
36.2\end{array}$ & $\begin{array}{c}1 \\
3.1\end{array}$ & $\begin{array}{c}19 \\
59.4\end{array}$ & $\begin{array}{c}3 \\
9.4\end{array}$ & $\begin{array}{c}9 \\
28.1\end{array}$ \\
\hline College library & $\begin{array}{l}30 \\
8.0 \\
\end{array}$ & $\begin{array}{l}315 \\
83.8\end{array}$ & $\begin{array}{l}20 \\
5.3\end{array}$ & $\begin{array}{l}11 \\
2.9\end{array}$ & $\begin{array}{c}5 \\
15.6\end{array}$ & $\begin{array}{c}20 \\
62.5\end{array}$ & $\begin{array}{c}1 \\
3.1 \\
\end{array}$ & $\begin{array}{c}6 \\
12.5\end{array}$ \\
\hline $\begin{array}{r}\text { University library } \\
\boldsymbol{f} \\
\%\end{array}$ & $\begin{array}{c}80 \\
21.3 \\
\end{array}$ & $\begin{array}{r}210 \\
55.9 \\
\end{array}$ & $\begin{array}{l}- \\
-\end{array}$ & $\begin{array}{c}86 \\
22.9 \\
\end{array}$ & $\begin{array}{c}2 \\
6.3 \\
\end{array}$ & $\begin{array}{c}18 \\
56.3 \\
\end{array}$ & - & $\begin{array}{c}12 \\
37.5 \\
\end{array}$ \\
\hline Other libraries & $\begin{array}{c}60 \\
16.0 \\
\end{array}$ & $\begin{array}{r}125 \\
33.2\end{array}$ & $\begin{array}{l}15 \\
4.0 \\
\end{array}$ & $\begin{array}{l}176 \\
46.8 \\
\end{array}$ & $\begin{array}{c}2 \\
6.3\end{array}$ & $\begin{array}{c}5 \\
15.6\end{array}$ & $\begin{array}{c}1 \\
3.1\end{array}$ & $\begin{array}{c}24 \\
75.0\end{array}$ \\
\hline
\end{tabular}

Note: $1=$ Excellence; $2=$ Good; $3=$ Poor; $4=$ Not used.

Source: Author's estimations.

\section{Conclusions and Suggestions}

The teachers of both the General Degree Colleges (GDCs) and Teachers' Training Colleges (TTCs) of West Bengal State University (WBSU) differ in the nature of their information seeking behaviour, making different choices among the available resources. Even though one could argue that no major differences are found in the information seeking behaviour between the teachers of both the groups under the university, the present study highlights quite interesting as well as important diversities. It is shown that the TTC teachers need more information on educational software and research works for writing books and articles and participating in seminars and workshops, while the teachers of the GDCs seek more information for preparing their class lectures and on the latest developments in the subject field. So, the General 
Degree College teachers mostly focus on making the students achieve better results in the examinations. On the other hand, the teachers of the TTCs are more engaged in conducting research and writing books compared to GDCs. It could be concluded that the teachers in GDCs have a lower level of information seeking skills particularly pertaining to getting updates relevant to research. This inability to acquire information effectively could negatively affect their capability to recognize and efficiently cover their needs on that field. As a result, the teachers of GDCs should engage more in research activities.

Moreover, the teachers of both groups refer to a quite wide range of information sources. The teachers of the GDCs seek information mostly from journals, reference books and newspapers, whereas the TTC teachers mostly prefer to consult with their colleagues and refer to text books, research reports and electronic databases. Reference books are the most preferred sources for research work to the teachers of the TTCs, while the GDC teachers mostly prefer journals. Based on these findings, it is highly recommended that the college libraries provide a greater variety of journals, reference books, text books and electronic documents.

Even during the modern era of technology, almost all the teachers depend mainly on printed documents, while a change is gradually taking place in the academic community. Search engines are gradually starting to become popular among teachers, with many of them using audiovisual materials and electronic documents while they deliver their lectures in the classroom. This shift in preferences has brought about a marked and sustained change in the overall attitude of the college teachers towards information resources. The majority of them often tend to use the library outside their own institution to get the pieces of information they need while they are only moderately satisfied by their own institution's library services. Hence, the college library should re-engineer its services, by providing internet facilities and software training to the users.

In summary, the present study suggests that the time when the college libraries will be set up with sufficient resources and internet facilities, assisting all their users in solving their day to day problems by supplying their required information, should come as soon as possible. By the time that this necessary library reform will take place, the grass root of college libraries will be subject to such a great infrastructure improvement that based on this new foundation our country's education system will be able to reach greater heights.

\section{References}

Ahenkorah-Marfo, M., Teye, V., \& Senyah, Y. (2011). Information seeking behaviour of faculty: the case of the College of Science, Kwame Nkrumah University of Science and Technology, Kumasi, Ghana. Journal of Science and Technology, 31(1), 89-96.

Challener, J. (1999). Information Seeking Behaviour of Professors of Art History and Studio Art. Kent University. ERIC. Retrieved from http://1.usa.gov/1U3I6HG.

Lewin, D., \& Stokes, J. P. (2004). Information seeking behaviour of nurse teachers in 
a school of health studies: a soft system analysis. Nurse Education Today, 24(1), 47-54.

Qureshi, M. T., Zafar, K. M., \& Khan, B. (2008). Information needs and seeking behavior of students in universities of Pakistan. Journal of Applied Sciences Research, 4(1), 40-47.

Patitungkho, K., \& Despande, N. J. (2005). Information seeking behaviour of faculty members of Rajbhat University of Bangkok. Webology, 2(4), 51-62.

Pattanaik, P. K., \& Parida, B. (2008). Information needs seeking pattern of users of Orissa University of Agriculture and Technology, Bhubaneswar: A User Study. In IASLIC National Seminar, 22 ${ }^{\text {nd }}$, Bose Institute Kolkata, December (498-507). Kolkata: IASLIC.

Rafiq, M., \& Ameen, K. (2009, February 19). Information seeking behaviour and user satisfaction of university instructors: a case study. Library Philosophy and Practice. Retrieved from http://bit.ly/1LPqRad.

Sethi, A. (1990). Information seeking behaviour of social scientists: an Indian conspectus. New Delhi, ND: Hindustan Publishing Corp.

Shanmugam, A. (1999). Information seeking behaviour of trainee teachers in selected teacher training colleges in Malaysia. Malaysian Journal of Library and Information Science, 4(1), 1- 26.

Shooken, A., \& Kushik, S. K. (2002). Information seeking behaviour of social scientists of Haryana University. Library Herald, 4(1), 8-11.

Suriya, M., Sangeeta, G., \& Nambi, M. A. (2004). Information seeking behaviour of faculty members from government arts colleges in Cuddalore district. In H. K. Kaul and S.K Patil (Ed.). Library and Information Networking (pp. 285-292). New Delhi:NACLIK.

Tahir, M., Mahmood, K., \& Shafique, F. (2008). Information needs and information seeking behaviour of arts and humanities teachers: a survey of the University of the Punjab, Lahore, Pakistan. Library philosophy and Practice, Retrieved from http://bit.ly/1h2fssd.

Thanuskodi, S. (2009, June 22). Information seeking behaviour of law faculty at Central Law College, Salem. Library Philosophy and Practice. Retrieved from http://bit.ly/1MsRSAM.

Watson, D., Blakeley, B., \& Abbott, C. (1988). Researching the use of communication technologies in teacher education. Computers \& Education, 30(1/2), 15-21.

Wilson, T. D. (2000). Human information behaviour. Information Science, 3(2), 4955. 
